\title{
'When Sport Met Ideology and Colonial Bitter Memories': The Impact of the 1964 Tokyo Olympics on North and South Korean Sports
}

Jongsung Lee*

\section{Introduction}

Over the course of the twentieth century, Korea underwent very unfortunate and tragic experiences from Japanese colonization to the Korean War and the split into two states, the communist North and the capitalist South. Consequently, it was natural that South Korea was subsumed into the Cold War and that South Korean society was filled with strong antiJapanese sentiments.

It is beyond doubt that South Korean society has been characterized by anti-communism and anti-Japanese feelings. However, there were other complex aspects to the two most dominating political and social tenets in South Korea. It cannot be denied that the people residing in North and South Korea had a common ethnic background. This racial homogeneity impacted North and South Korean relations despite their different political and economic systems in an age of the Cold War where the global competition between the United States and the Soviet Union fiercely developed and rapidly spread to every field. ${ }^{1}$

\footnotetext{
* Assistant Professor, Department of Sports Industry \& Management, Hanyang University at Seoul, South Korea

1 David L. Andrews and Stephen Wagg, "Introduction: War minus shooting?," eds.
} 
In addition, anti-Japanese sentiment in South Korea became a paradoxical problem. In many respects, the South Korean government in the 1960s increasingly needed to establish diplomatic ties with its previous colonial masters although antagonism mainly emanating from bitter memories against Japanese oppressive colonial rule was very strong. At the time, the top priority of the military government was to carry out economic development and to enhance the living standard of its people. ${ }^{2}$ Moreover, America's strong objective of constructing an East Asian anticommunism alliance pressured Japan and South Korea to normalize their relations under the guise of economic cooperation. ${ }^{3}$ However, the 1965 treaty between Japan and South Korea was limited and unsatisfactory for the South Koreans in that Japan paid reparations in terms of economic assistance without an apology for its colonization of Korea. ${ }^{4}$ This was the reason behind the South Koreans' strong dissatisfaction to the treaty and why some of them took to the street to censure the humiliating diplomacy. In this transition period after the signing of the treaty, Japan, which had been merely a bitter enemy and rival to South Korea, became recognized as a role model for South Korean economic development.

The 1964 Tokyo Olympics revealed the paradoxical realities for the two Koreas: The Cold War sporting rivalry and ethnic homogeneity between them, along with the simultaneous antagonism and sense of envy towards Japan. These conflicting sentiments, which must have been experienced by North and South Koreans, through a series of events in Tokyo in 1964 are closely related with the major themes of this essay.

The Tokyo Olympics were the first Olympics for North and South Ko-

Stephen.Wagg and David L.Andrews, East Plays West: Sport and the Cold War (NY: Routledge, 2007), 1-9.

2 Chŏng Jaechŏng, Chuje-wa Chaengchŏm-ŭro Iknün 20 saeki Hanilkwankyesa (Seoul: Yŏksapipyŏngsa, 2019), 92.

3 Cho Heeyeon, Park Chung Hee-wa Kaebaldokjaesidae (Seoul: Yŏksapipyŏngsa, 2007), 71-2.

4 Chŏng, 20 saeki Hanilkwankyesa, 123-27. 
rea, both of which were in earnest exposed to the global sports arena. ${ }^{5}$ The Tokyo Olympics also functioned as a prelude to the peppery sporting rivalry between the two Koreas over the ensuing decades.

However, North and South Korea could perceive that they shared the same ethnic background at the Tokyo Olympics. A world record holding North Korean female athlete, Sin Kŭmtan, was a case in point. She was not allowed to participate in the Olympic Games because she had participated in the Games of the Newly Emerging Forces (GANEFO). This ban would later catalyze the withdrawal of the North Korean contingent. Yet, she had a brief encounter with her father in Tokyo in 1964 after their separation since the Korean War, a tearful episode which reminded the South Koreans of a proverb: Blood is thicker than water. This kinship would be repeatedly exploited as a popular subject of sports politics and diplomacy in the form of cooperation between North and South Korea, which was contrasted with the former divided Germany where the East and the West used sport to establish distinctive national identities. ${ }^{6}$

From a wider perspective, the origins of the Cold War rivalry between the two Koreas that took place in Tokyo in 1964 could also provide a clue as to how the Cold War was becoming inextricably woven into sport in East Asia in general and in the Korean Peninsula in particular. To understand East Asian sports politics, the GANEFO and the two Chinas' situation in the Olympics needs to be discussed. China withdrew from the Olympic movement in 1958 in protest against Taiwan's participation in the 1956 Olympics and the former instead lent its energies to develop an alternative Olympic Games for the Third World in collaboration with Indonesia. China fully supported the GANEFO in an attempt to challenge the Western-dominated IOC: China did not merely dispatch a large con-

5 Han Sŏkchŏng, Manchu Modern: 60 Nyŏndae Hankuk Kaebal Cheje-ŭi Kiwŏn (Seoul: Munhak-gwa Chisŏngsa, 2016), 374-75.

6 Udo Merkel, "Sport, Politics and Reunification - A Comparative Analysis of Korea and Germany," The International Journal of the History of Sport 26, no 3 (Feb 2009): 406-28. 
tingent but also offered to defray the expenses of economically destitute Third World nations that aspired to partake in the GANEFO in 1963 . $^{7}$ North Korea actively participated in the GANEFO but this would become a cause of its withdrawal from the Tokyo Olympics as briefly discussed in the case of Sin Kŭmtan.

While China tried to create an alternative to the Olympics, North Korea never gave up on their participation in the Olympics. Indeed, North Korea was allowed to participate in the Tokyo Olympics as an independent team in the wake of unsuccessful negotiations for a combined Korean team with their southern adversary. South Korea, which had already participated in the Olympics under the name of Korea since 1948, rejected the idea of one Korean team formulated by the IOC on the German model. ${ }^{8}$

North Korea seemed quite confident in the forthcoming sporting battle against its ideological foe. Until the Tokyo Olympics opened, North Korea had a comparative edge in terms of spotting promising athletes and training them systematically. North Korea had undertaken a sports promotion policy based on state amateurism since 1950s and further concentrated on the development of Olympic athletes after $1964 .{ }^{9}$ One of the notable results was the miracle of the North Korean football team in the World Cup in 1966 with its distinctive attacking style based on the Party's underlying value Chuche, an idea that Marxist-Leninism could creatively and independently be adapted to the actualities of North Korea's situation by rejecting flunkeyism. ${ }^{10}$

7 Guoqi Xu, Olympic Dreams: China and Sports 1895-2008 (Cambridge: Harvard University Press, 2008), 51-87.

8 Allen Guttman. The Olympics: A History of the Modern Games, Second Edition (Urbana and Chicago: University of Illinois Press, 2002), 110. See also for further detail on the negotiations. Brian Bridges, "Reluctant Mediator: Hong Kong, the Two Korea and the Tokyo Olympics," International Journal of the History of Sport 24, no. 3 (March 2007): 375-91.

9 Lee Hangnae and Kim Dongsun, Pukhan-ŭi Ch'eyuk (Yongin: Hankuk Haksuljŏngposa, 2001), 181.

10 Lee Jongsung, A History of Football in North and South Korea C. 1910-2002: 
On the contrary, South Korea embarked on a grand plan to outperform North Korea's centralized and highly effective national sports training system after 1964. As the first ever sporting contest between North and South Korea in the Olympics was imminent, South Korea had to be full ready for the Olympics and a heavy burden was, of course, placed on its Olympic delegation.

Moreover, the complex situation of 600,000 Korean residents in Japan, who were divided by the pro-North Korean organization Choch'ongryŏn and the pro-South Korean organization Mindan, further stimulated the competitive spirit of the two Koreas. During the Tokyo Olympics, a large number of impoverished Koreans in Japan, most of whom had been conscripted and forced to hard labor during the colonial period, became an object of the ideological confrontation between the two Koreas. It is a significant testament that the tragic consequences of Japanese colonialism were directly linked with the Cold War in 1964.

North and South Korea had another good reason to attach deep political significance to the Tokyo Olympics. This was partly due to the fact that by the time the Tokyo Olympics were held, the two Koreas, despite their resentment toward Japan, had to collaborate with their former colonizer for economic and diplomatic reasons. Under these circumstances, from the Tokyo Olympics in 1964, North and South Korea seemingly began to be incorporated into the world of politicized sporting mega-events.

The first Olympics held in Asia, the Tokyo Olympics in 1964 was an emblem of Japan's rapid economic development and its acceptance to the global community, shedding its image of an international pariah. ${ }^{11}$ In retrospect, the Tokyo Olympics would provide an important forum for the host nation both to put it on the world map and to be separated from its shadowy past. In athletic terms, the success of Japanese athletes harvest-

Development and Diffusion (Oxford: Peter Lang, 2016), 76.

11 Allen Guttmann and Lee, Thompson, Japanese Sports: A History (Honolulu, University of Hawaii Press, 2001), 166. 
ing a total of twenty-nine medals in the Tokyo Olympics was startling. ${ }^{12}$ Their overwhelming achievement was shocking enough to propel South Korea to develop its own national sport promotion project. The South Korean government had to carry forward an elaborate sports scheme to keep abreast of its former colonial master amid the rise of anti-Japanese sentiment in South Korea that was mainly generated by the humiliating treaty signed with Japan.

However, overcoming Japan in the sports field was not an easy task for South Korea. Thus, South Korea was compelled to take a pragmatic stance by emulating Japan's sophisticated sports system and promoting sports exchange with Japan. South Korean pragmatism at the expense of nationalism also suggested that South Korea attached the utmost significance to the forthcoming full-scale ideological battle against North Korea in the sports arena. These changing dynamics were initiated at the Tokyo Olympics with the remarkable success of Japanese athletes and the North Korean threat.

\section{The Two Korea's Invisible Battle at the Tokyo Olympics}

Leading up to the Tokyo Olympic Games, the South Korean government poured a great deal of money into setting up an Olympic training team for the organized and intensive training of its nation's foremost athletes in 1963 to prepare for the possible contest against North Korea in Tokyo, a measure that was hitherto unprecedented. ${ }^{13}$ North Korea would indeed be permitted to participate in the Olympics later the same year although its official name, Democratic People's Republic of Korea (DPRK) could not be used, which was contrary to its request. ${ }^{14}$ In 1963,

12 Guttmann and Thompson, Japanese Sports, 198.

13 “I Hyae- ŭi Sports (14) Haptonghunryŏntan,” Donga Ilbo, December 25, 1963.

14 "Uri Nara Olympic Wiwŏnhoe Kukche Olympic Wiwŏnhoe-ŭi Chungsik Hoewŏnŭro Kaip," Nodong sinmun, October 22, 1963. 
North Korea had a successful rehearsal for the Tokyo Olympics by winning many gold medals with three world records in athletics and weightlifting at the first GANEFO held in Indonesia. ${ }^{15}$

Amidst these heated preparations in North and South Korea, Mindan and Choch'ongryorn played an instrumental role for the two Korean Olympic teams. Mindan, which was comprised of pro-South Korean members with Korean descent in Japan, formed an association for supporting the South Korean Olympic delegation and they gave their full material and emotional support. Apart from their enthusiastic cheering for the South Korean team, they collected significant funds that were to be spent on the training of promising South Koran athletes in Japan and on travel expenditures of South Korean sports figures. ${ }^{16}$ In an interview with the South Korean press, the president of the association explained the reason for their assistance for the South Korean team as follows: It was because through the Tokyo Olympics, the success of South Korean athletes could boost the morale of approximately 600,000 Korean compatriots in Japan who had pent-up frustration due to Japanese discrimination. He went on to ask South Korea to not lose to North Korea at the Olympics. ${ }^{17}$ The association also pushed forward a plan of inviting South Koreans to Japan who had separated relatives or family members living in Japan around the time of the Tokyo Olympics. This plan would later materialize with the help of South Korean and relevant Japanese authorities. $^{18}$

15 "Uri Sŏnsutŭri Talsŏnghan Pitnanŭ Sŏngkwa," Nodong sinmun, November 24, 1963.

16 Yun Kŏncha, Zainich-ŭi Chŏngsinsa, trans, Pak Chinwu (Seoul: Hankyŏrae Chulpansa, 2015), 520; Min Kwansik, "Ǔratchacha 88 sae Chŏngnyŏn 17. 64 nyŏn Ilbon Pangmun," Chungang Ilbo, November 15, 2005; "Cheyuk Kwankyecha Olympic Kwanramtan Pakyŏn,” Donga Ilbo, July 16, 1964; Kim Namsŏng, Mindan 60 nyŏn Pihwa, Wŏlgan Chosŏn, March, 2009, 190.

17 "5 punkan Interview Cheilkyopo Huwŏn Hoechang Lee Yu Chŏn si," Kyŏnghyang sinmun, August 26, 1964.

18 “Namnyŏnoso Kakyekakchŭng...Kipŭm-e Tŭltŏ Kwankwang Inpa,” Donga Ilbo, 
Choch'ongryŏn, the rival organization to Mindan, was very active in supporting the North Korean Olympic team. The pro-North Korean organization viewed the Tokyo Olympics as an arena for a massive propaganda campaign. At the time, Choch'ongryŏn extended its sphere of influence within the Korean-Japanese community by aggressively sending many impoverished and socially discriminated Koreans in Japan to North Korea. The mass repatriation of Koreans in Japan to North Korea started in $1959 .{ }^{19}$ The repatriation could be realized as it basically corresponded with the national interests of both North Korea and Japan. For North Korea, the influx of Koreans from Japan meant not only an increase in ablebodied workers to contribute to reconstruction, but also a vehicle for its political propaganda of securing dominant status over South Korea in the international society. ${ }^{20}$ For Japan, the former colonial subjects living in Japan who were generally impoverished, unemployed and ghettoized were a thorny problem in that the financial burden of destitute Koreans on Japanese government institutions was substantial. Henceforth, their return to North Korea was whole-heartedly supported by the Kishi administration despite South Korean obections. ${ }^{21}$ Against this political backdrop, Choch'ongryŏn aggressively encouraged ethnic Koreans in Japan to return to North Korea and 93,000 of them left for the communist nation from 1959 to $1984 .{ }^{22}$ Discriminated by the Japanese and were destitute, many g boarded ships heading for North Korea, the earthly paradise. This was the image of North Korea that Choch'ongryŏn propagated in an attempt to let as many Koreans in Japan as possible join in the exodus. A future professional baseball manager in South Korea, Kim Sŏngkŭn, who was a Korean living in Japan, barely avoided repatriation to North Korea.

October 8, 1964; "Tongkyŏng Olympic Tŭkpawŏn Suchŏp (3) Hyŏnhaetan Kŏnnŏkan Hankukin Kwanramkaek,’ Donga Ilbo, October 30, 1964.

19 Yun, Zainich-ŭi Chŏngsinsa, 414-15.

20 Chŏng, Chuje-wa Chaengchŏm-ŭro Iknŭn 20 saeki Hanilkwankyesa, 182-83.

21 Tessa Morris-Suzuki, Exodus to North Korea: Shadows from Japan's Cold War (Lanham: Rowman \& Littlefield Publishers, 2007), 98-153.

22 Chŏng, Chuje-wa Chaengchŏm-ŭro Iknŭn 20 saeki Hanilkwankyesa, 180-90. 
Largely at the insistence of his elder brother, he came close to going North Korea with his family. Having experience visiting South Korea for playing baseball games, Kim persuaded his elder brother not to go to North Korea, while showing some pictures from South Korea. He later recounted this episode as follows: "If I had gone to North Korea at the time, I would have not played baseball, which is unimaginable to me." 23

Those who were repatriated to North Korea tended to donate their property to Choch'ongryŏn and these large sums of money greatly helped its various activities for North Korea, notably persuading Korean people in Japan to join. ${ }^{24}$ Inspired by the news of North Korea's participation in the Tokyo Olympics, Choch'ongryŏn gave the North Korean team the red carpet treatment by spending its funds on maximizing the impact of North Korean political propaganda. The North Korean team was welcomed by a multitude of Choch'ongryŏn members waiting for their arrival at the dock in Niigata, where they prepared posters and balloons to celebrate their participation. ${ }^{25}$ The members of Choch'ongryŏn also devoted themselves to luring South Korean Olympic tourists to apply for repatriation for North Korea, a stratagem that was partly successful. Seven South Korean tourists showed their intention to go to North Korea and one of them, in fact, boarded the ship. ${ }^{26}$ In addition, Choch'ongryŏn had to prepare for such possible contingencies as the defections of North Korean athletes since the Japanese government allowed political asylum during the Tokyo Olympics. Thus, Choch'ongryŏn recruited and trained 2,000 body guards to keep North Korean athletes under close guard. ${ }^{27}$

The pro-North Korean organization provided many athletes of the

23 Kim Sŏngkŭn, Kolchi-rŭl Ildŭng-ŭro, (Seoul: Chaŭm-kwa Moŭm, 2009), 81-2.

24 Yun, Zainich-ŭi Chŏngsinsa, 419-20.

25 "Hyŏlyŏn-ŭi Chŏngto Kuchin Mupyochŏng-ŭi Pyochung," Kyŏnghyang sinmun, August 26, 1964.

26 "Ochŏm Namkin Olympic Kwankwang," Kyŏnghyang sinmun, November 25, 1964

27 “Tongkyŏng Olympic Tŭkpawŏn Suchŏp (2) Kyopo-ka Moŭnton ilŏkwŏn,” Donga Ilbo, October 20, 1964. 
North Korean team with a provisional residence at Chosŏn University, due to the team's refusal to enter the Olympic village in protest against the decision of the Tokyo Olympic Organizing Committee (TOOC) which did not permit any track-and-field athletes and swimmers who had participated in the GANEFO games to enter the village. ${ }^{28}$ At the time of the Tokyo Olympics, the International Amateur Athletic Federation (IAAF) and the International Swimming Federation took a strong stand on GANEFO. The two international sports federations prevented eleven Indonesian and six North Korean athletes, who had competed in the GANEFO games from participating in the Olympics. This suspension would eventually give rise to the last minute withdrawal of the entire Indonesian and North Korean teams on the eve of the Olympics Opening Ceremony. ${ }^{29}$

From the North Korean point of view, this withdrawal might have been a natural consequence since Sin Kŭmtan, who was disbarred from competing in the Olympics, was its best prospect for a gold medal. Since North Korea aspired to gain ascendancy over South Korea, it had to make an effort to lift the Olympic ban on Sin. One of the Choch 'ongryŏn's amicable organizations comprising of leftists in Japan also demanded the withdrawal of the ban to the TOOC. ${ }^{30}$ The ban, however, was not rescinded by the IAAF, which spurned the request from its Japanese members on lifting the ban. ${ }^{31}$ It was a particularly painful decision for North Korea since other international sports federations, save for the two aforementioned federations, had withdrawn their suspensions on the 'GANEFO athletes.'

For North Korea, Sin Kŭmtanwas not simply a great athlete who held

28 "GANEFO-e Chamkahan Sŏnsutŭl-ŭi Ipchon Kŏpumyŏn Chŏnpu Antŭlŏka," Donga Ilbo, October 7, 1964; Yun, Zainich-ǔi Chŏngsinsa, 447.

29 John Slater, "Tokyo 1964", in Encyclopedia of the Modern Olympic Movement, eds. John. Findling and Kimberly Pelle (Westport, CT: Greenwood Press, 2004), 169; Guttmann, The Olympics, 110.

30 "Ilbon-ŭi Kwangpŏmhan Sahoekye-ka Uri Nara Sŏnsutŭl-e Taehan Putang'han Cheche Chochi-rŭl Chŏlhoehalkŭsŭl Yoku," Nodong sinmun, September 7, 1964.

31 “Oryun Chulchŏn Motatorok," Kyŏnghyang sinmun, November 25, 1964. 
two world records in the women's 400 and 800 meters. ${ }^{32}$ She was extolled by the Worker's Party in North Korea as an iconic figure in the Ch'ollima movement in which the state compelled many North Koreans to undertake hard labor to quickly complete the reconstruction of major industries. This movement laid a foundation for the rapid development of the North Korean economy in the 1950s and 1960s, which 'far outdistanced that of South Korea. ${ }^{33}$ The North Korean Party organ, the Nodong sinmun, praised her as an emblematic sports figure in the age of Ch'óllima by putting a stress on her endurance derived from restless training, never skipping running on rainy days or Sundays. ${ }^{34}$ Her reputation as a symbol of Ch'óllima was not confined to North Korea. Even a Chinese journalist estimated that she ran at the speed of Ch'ollima in the 1963 GANEFO after establishing her two world records. ${ }^{35}$ Although, in the Tokyo Olympics it was impossible to foresee Sin becoming a household name in South Korea. She and her father who lived in South Korea could meet each other after fourteen years of separation due to the Korean War through the good offices of the TOOC just prior to her return to North Korea. ${ }^{36}$ Such a tragic reunion for only no more than five minutes because of the North Korean team's tight schedule struck a chord with many South Koreans, which resulted in a series of record releases in South Korea on the theme of their reunion and separation. ${ }^{37}$ The South Korean government, however, aptly exploited this brief and sad reunion as a

32 "Hoeng'sŏlsusŏl," Donga Ilbo, October 6, 1964.

33 Bruce Cummings, Korea's Place in the Sun: a Modern History (New York, W. W. Norton \& Company, 2005), 433-4.

34 Chŏng Kiho, "Ch'ŏllima Sitae-ŭi Cheyukin Sin Kŭm Tan Sŏnsu," Nodong sinmun, July 3, 1962.

35 Bi-hua Xu, “Canlande Diyiye,” Xinwen Zhanxian, February, 1964, 36.

36 "Tanchang-ŭi 38 sŏn Sekyerŭl Ulryŏta," Donga Ilbo, October 10, 1964; Kim Kwanghi, “A, Kŭm Tan a Aekŭlnŭn Maŭm,” in Sports-wa Hamkyehan Yŭlkwangŭi Sewŏl, ed. Hankuk Cheyuk Unroninhoe (Seoul: Chei \& Chei Media, 2015), 5962.

37 “Sotajin Sin Kŭm-tan Norae,” Kyŏnghyang sinmun, October 28, 1964. 
propaganda opportunity to condemn the inhumane nature of the North Korean regime at the behest of President Park and held a mass rally to promote fraternity between North and South Koreans at Seoul as well as to denounce the communist nation. ${ }^{38}$

While North Korea, to a great extent, attached its political significance on Sin for the forthcoming Tokyo Olympics, South Korea particularly focused its attention on a Korean compatriot in Japan, Kim Ǔit'ae who was a Korean resident in Japan and member of the South Korean national judo team. Kim was considered to be a medal favorite in South Korea since he took fourth place in the World Judo Championship at Paris in 1961 when there was no weight classification in judo. The weight classification would be instituted just before the Tokyo Olympics. ${ }^{39}$

He was also portrayed as a champion of democracy by the South Korea media. He rejected Choch'ongryŏn's suggestion to play for North Korea in lieu of South Korea on the grounds that his elder cousin had been killed by a North Korean soldier during the Korean War. ${ }^{40}$ This image of him was particularly important for South Korea and Mindan, considering that the repatriation to North Korea led by Choch'ongryŏn was in full swing among the Korean community in Japan.

In the Tokyo Olympics, judo was rated one of the most important Olympic sports amongst the Japanese because the Japanese traditional sport had been included in the Olympic program as the first Olympic sport with non-Western origins. It is unsurprising that there were great expectations of a clean sweep of all four gold medals in judo in Japan. Two of the foreign judo players who were able to shatter the Japanese

38 "Pukkoe-ŭi Piindochŏk Chŏsa Kyutanhanŭ Yŏron Chosŏnghara," Donga Ilbo, October 13, 1964; "Onŭl Chukyŏng Yesanan Tongkwa," Kyŏnghyang sinmun, October 13, 1964; "Sin Kŭm Tan Punyŏ-ŭi Pikŭk," Donga Ilbo, October 17, 1964.

39 Ohsima Hiroshi, Tamasiino Soukoku Zainichi Supotsu Eiyu Retsuden (Tokyo: Kodansha, 2012), 142; “2 nyŏnyŏ-ŭi Sanko," Donga Ilbo, August 29, 1964.

40 "Yuto Kim Ǔi-tae," Kyŏnghyang sinmun, October 22, 1964; Ohsima, Tamasiino Soukoku, 143. 
dream were Holland's Anton Geesink and South Korea's Kim Üit'ae. ${ }^{41}$ However, it was Geesink who defeated Kaminaga Akio in the open class, an upset which led the Japanese to feel, 'a kind of collective sorrow. ${ }^{42}$ Kim was defeated by Okano Isao in the middle weight semi-finals, but the former would gain a bronze medal. Kim had solidified his determination of winning the Olympics for the Korean people in Japan and might have been somewhat disappointed by the result. ${ }^{43}$ This was the reason he burst into tears when he lost to Okano.

However, he became a national hero in South Korea when it was reported in many South Korean newspapers that he had rebuffed not merely Choch'ongryön's suggestion of playing for North Korea but the proposal of his old school, Tenri University in Nara, regarding his participation in its Soviet tour that included wearing a judo uniform with the logo of the Japanese national flag. ${ }^{44}$ Touched by his athletic effort and strong national spirit, President Park invited him and his family to South Korea and some South Korean companies gave presents to him. ${ }^{45}$ When he visited the Blue House, the South Korean presidential residence, President Park praised his athletic achievements and consoled him in fluent Japanese saying, 'The difference between first place and second or third place is paper-thin. ${ }^{46}$ In an interview with his father in the Kyŏnghyang sinmun, he bemoaned that the Korean community was split along ideological lines and said, "Choch'ongryŏn must have envied our visit to South Korea."

\section{Ohsima, Tamasiino Soukoku, 144.}

42 Guttmann and Thompson, Japanese Sports, 198.

43 "Sawŏ Ikyŏyahanta Medal Yumangchu Judo," Kyŏnghyang sinmun, October 19, 1964.

44 Ko Tuhyŏn, Ǔri-to Haenaelsu Itta: Hankuk Olympic Tochŏn Panseki (Seoul: Hankuk Pangsong Saŏptan, 1982), 154-55; "Yuto Kim Ǔi-tae," Kyŏnghyang sinmun, October 22, 1964.

45 “28 il Mokuk Pangmun," Kyŏnghyang sinmun, November 27, 1964; "Kim Ǔi-tae Sŏnsu-e Yangpokkam-tŭng Sŏnmul,” Donga Ilbo, November 30, 1964.

46 Ohsima, Tamasiino Soukoku, 146.

47 “Medalist-ǔi Puchin Kim Kil-yong Si,” Kyŏnghyang sinmun, November 30, 1964. 
The sporting feat accomplished by Kim as a South Korean rather than a North Korean judo player was important for Mindan since it had provided great assistance to the South Korean delegation for the Tokyo Olympics, partly in pursuit of undermining the leverage of Choch'ongryön in the Korean community in Japan. In the wake of the Olympics, Mindan's endeavor for the ideological battle came to fruition. It was transpired that 449 Choch'ongryŏn members were converted to the pro-South Korean organization, Mindan. ${ }^{48}$ The competition between Mindan and Choch'ongryŏn became intensified in this way in 1964.

\section{The Rise of Sports Nationalism in North and South Korea}

From the perspective of political propaganda, the North Korean Olympic football team had meaningful experience with a pro-Pyŏngyang Korean football club in Japan, although the North Korean athletes including Sin Kŭmtan did not participate in the Tokyo Olympics. The North Korean footballers introduced their own up-tempo football style to the pro-North Korean footballers in Japan. ${ }^{49}$ At the time, Choch'ongryŏn concentrated on rebuilding its network of Korean community schools in Japan and in the process, football became an important means to form strong ties to North Korea within the schools. A pro-North Korean high school football team in Tokyo that was supported by Choch'ongryŏn would later visit North Korea and meet Kim Il-sung, the North Korean supreme leader, in $1972 .^{50}$

In the meantime, North Korean sports in general and football in particular sought to find other stages to display their athletic skills after the

48 "Choch'ongryŏn-kye 449 myŏng Olympic Kyeki-ro Chŏnhyang," Chosŏn Ilbo, December 12, 1964.

49 "Irum-ŭl Nalriko Itnŭn Cheil Chosŭn Chukkutan," Nodong sinmun, January 9, 1965.

50 Yun, Chainich-ŭi Chŏngsinsa, 527. 
disappointing boycott from the Tokyo Olympics. In 1965, the Nodong sinmun gushed over the two brilliant sporting achievements made by a female skater and male table tennis players in the global arena. ${ }^{51}$ However, these victories were not sufficient enough to appease their resentment stemming from the ban on Sin at the Olympics. Instead, their ambitious objective was presumably the World Cup finals, which would be held in 1966. As a rehearsal to the World Cup preliminaries, North Korea hosted the Asian Football GANEFO by inviting five national teams in 1965. During this tournament, North Korea also cultivated friendships with the participating non-aligned Third World nations. ${ }^{52}$ After the tournament, Sin brought the discontent generated from the ban to the fore once again while praising the value of GANEFO: 'The imperialists and their slaves hated the GANEFO like an eyesore,' despite its noble ideals of promoting 'friendship, solidarity and common prosperity,' and 'I feel indignant whenever I recall their illegal sanctions against the GANEFO participants at the time of the Tokyo Olympics. ${ }^{53}$

As North Korean football shook the football world by defeating Italy at the England World Cup in 1966, the North Korean press appraised their unique tactics of 'all-out defense and all-out offense' which had been created in line with the idea of Chuche. ${ }^{54}$ The idea was decreed by the North Korean Worker's Party in 1958, at a time when Sino-Soviet relations had worsened and pressured the Party to develop a more independent stance between the two communist giants. ${ }^{55}$ Under these political circumstances,

51 "Han Pilhwa Sŏnsu 3chŭn meter Kyŏngki-esŏ Che 4wi," Nodong sinmun, February 9, 1965; "Uri Nara Tim Che 3wi-rŭl Chaengchwi,” Nodong sinmun, April 21, 1965.

52 “Asian Football GANEFO Closes,” The Pyŏngyang Times, August 19, 1965.

53 Sin Kŭmtan, "Torch of GANEFO will burn forever," The Pyŏngyang Times, December 2, 1965.

54 "Priceless Experience and Serious Lessons," The Pyŏngyang Times, August 4, 1966; Kim Pyŏngha et al., Urinara Chukku (Pyŏngyang: Cheyuk Chulpansa, 1963), 20-21.

55 Cummings, Korea's Place in the Sun, 413-14. 
Chuche also began to permeate into all cultural and sporting practices. In this sense, the athletic achievements of North Korean football with its distinct style in 1966 had symbolic implications in which the idea of Chuche was successfully demonstrated in practice. As such, North Korea found another way to put on display its athletic skills in its own style after the Tokyo Olympics.

Meanwhile, South Korea had to make massive changes in its elite athletics after 1964 and established the national training center. The foundation of the training center was masterminded by Min Kwansik, president of Korea Sports Association (KSA), who was particularly impressed by the superb infrastructure of Japanese sports at the Olympics. ${ }^{56}$ It would later become a cornerstone for nurturing South Korean sports talents with an intensive and scientific way during the sporting rivalry between North and South Korea.

The South Korean athletes were met with harsh criticism for their poor results at the Tokyo Olympics, which did not live up to their people's expectation. Given that the number of South Korean athletes participating in the Tokyo Olympics was the largest ever and a great deal of national expenditures were spent on their two years of training, such strong public criticism throughout the nation was not surprising. ${ }^{57}$ To make matters worse, the tremendous success of Japan in the Olympics, ranking third with sixteen gold medals, was in stark contrast with South Korea. The disparity between the two countries instigated already inflamed popular sentiments. ${ }^{58}$ After the Tokyo Olympics, Min Kwansik claimed that the

56 Hŏ Chinsŏk, Sports Konghwakuk-ŭi Tansaeng (Seoul: Tongkuk Taehakkyo Chulpanpu, 2010), 144-45.

57 Ko, Ǔri-to Haenaelsu Itta, 149-50; “2 nyŏnyŏ-ŭi Sanko,” Donga Ilbo, August 29, 1964.

58 Jessamyn R. Abel, "When Athletes Are Diplomats: Competing for World Opinion at the Tokyo Olympiads," in The East Asian Olympiads 1934-2008: Building Bodies and Nations in Japan, Korea, and China, eds. William Tsutsui and Michael Baskett (Leiden: Global Oriental, 2011), 57; "Hoeng'sŏlsusŏl," Donga Ilbo, October 23, 1964. 
level of South Korean sports was enhanced with three Olympics medals, despite the poor results in team sports. Min also insisted that the 1964 Olympics were meaningful for South Korea in terms of cultivating a spiritual bond with Koreans living in Japan. ${ }^{59}$

However, Min fell under criticism due to a controversy caused by the last-minute participation of the South Korean female volleyball team in the Olympics. Originally the North Korean female volleyball team was expected to participate in the Olympics, but instead their South Korean counterparts were unexpectedly invited to participate after North Korea's abrupt withdrawal. The TOOC implored the South Korean female team to play to spare a difficult and disgraceful situation in which only five teams rather than six would compete in female volleyball. ${ }^{60}$ The South Korean female volleyball team had not trained for eight months before arriving in Tokyo by charter flight arranged by the TOOC just one day before their first game in the Olympics. ${ }^{61}$ The participation of the South Korean team was particularly urgent for the TOOC since aside from judo, volleyball was another important Olympic sport for Japan in the Tokyo Olympics. This was because the Japanese female team had won the World Women's Volleyball Championship in 1962 and was a favorite in the Olympics. ${ }^{62}$

The female team's participation was, however, recognized by many South Koreans as purely a means to help Japan win a gold medal, and the sense of humiliation was exacerbated by a rumor that a portion of the cost for the charter flight was covered by Japan. ${ }^{63}$ When the Japanese female volleyball team triumphed at the Olympics, these public sentiments worsened enough for a politician to strongly interrogate Min Kwansik at the

59 "Ŏmhan Treining Kamtuchungsin-I Aswipta," Kyŏnghyang sinmun, October 26, 1964.

60 Ko, Ǔri-to Haenaelsu Itta, 134.

61 “Ŭri Yŏcha Paekutim 11 il-e Chulpal,” Donga Ilbo, October 10, 1964.

62 Ri Pyŏnghak, "Sekye Paeku Tangtalpo Manyŏ Kyŏngak," Hankyŏre sinmun, July 7, 1999.

63 "Yŏchŏk," Kyŏnghyang sinmun, October 31, 1964; "Yocha Paeku-ŭi Kyohun," Chungang Ilbo, Novermber 23, 2005. 
National Assembly regarding the rumor. ${ }^{64}$

This incident, it seems, was a microcosmic reflection of anti-Japanese sentiments in South Korean society amid reaching the final phase of the treaty signing between Japan and South Korea. The agenda of the treaty negotiation in the 1960s rapidly shifted to economic cooperation between the two countries and pragmatism, which was markedly in contrast with the two countries' diplomatic battles adhering to their political objectives in the previous decade. The South Korean government increasingly became aware of the need to establish a self-sustaining economy in the wake of cuts in economic assistance from America. The Japanese government then took advantage of the opportunity and offered, in the name of reparations, credit and grant aid for South Korea since it was difficult to make seed money to develop its economy. ${ }^{65}$ As the South Korean government moved to replace reparations with economic aid from Japan, massive national resistance erupted. In June 1964, the government declared emergency martial law to clamp down on a series of intensified demonstrations crying out for the resignation of the President Park. ${ }^{66}$

As many South Koreans thought of the treaty as a diplomatic humiliation, it could not be denied that economic assistance from Japan would be helpful for its economic development program and in constructing the Kyŏngbu expressway and a steel mill in Pohang. ${ }^{67}$ The Park's regime bore the brunt of public excoriation for its dependency on the economic power of Japan at the expense of South Korean national pride that preferred self-reliant modernization.

However, many South Koreans recognized that Japan had achieved a high level of economic growth through the Tokyo Olympics. One of the

64 “Olympic Mangsin,” Kyŏnghyang sinmun, October 30, 1964.

65 Yoshizawa Fumitoshi, Hyŏntae Hanil Munche-ŭi Kiwŏn, trans, Ri Hyŏnchu (Seoul: Ilchokak, 2019), 193-241; Chŏng, 20 saeki Hanilkwankyesa, 92-4.

66 Chŏng, 20 saeki Hanilkwankyesa, 98-103.

67 Yu Yongtae, Pak Chinwoo and Pak Taekyun, Hamke Iknun Donga sia Kunhyŏntaesa 2 (Pachu, Changpi, 2011), 159. 
novelties for some South Koreans was to watch TV broadcasts of Olympic sports taking place in Japan. An editorial in the South Korean press frankly expressed that Koreans were envious of the rising economic power of Japan and surprised at its science and technology capabilities to broadcast the event via satellite. ${ }^{68}$

The Tokyo Olympics were, indeed, referred to as 'the television Olympics' since they were the first to harness satellite transmission for television coverage and were televised with slow-motion instant replay and in color. ${ }^{69}$ At the time, the people in South Korea only listened to Olympic broadcasts on the radio but some South Koreans residing in Pusan could watch the broadcast through Japanese TV due to their closer proximity to the archipelago. ${ }^{70}$ From the early 1950 s, listening to Japanese programs on the radio and watching those on TV had already led to a flood of Japanese culture with the increased supply of TV sets in Pusan. ${ }^{71}$ South Korean radio and TV stations, with the assistance of the government, were established in Pusan to keep the Japanese influence at bay. ${ }^{72}$ Yet the impact of the Japanese media's spillover in Pusan was quite strong. As a South Korean TV station attempted to use the same channel through which they watched a Japanese TV, a vast majority of the people in Pusan, who were familiar with the programs of the Japanese public television, opposed the idea. ${ }^{73}$ A South Korean professor connected Japanese economic aid with an expanding presence of Japanese TVs in Pusan in a de-

68 “Che Sipal Hŏ Tongkyŏng Olympic Kaemak,” Donga Ilbo, October 10, 1964.

69 Slater, “Tokyo 1964," in Encyclopedia of the Modern Olympic Movement, 169.

70 "Sketch," Donga Ilbo, September 15, 1964; "Pusan-e TV Boom," Donga Ilbo (extra edition), October 11, 1964.

71 Kim Sŏngmin , Ilbon-ŭl Kŭmhata: Kŭmche-wa Yokmang-ŭi Hankuk Taechungmunwhasa 1945-2004 (Pachu:Kŭlhangari, 2017), 78-87.

72 Kang Chunman, Hankuk Taechung Maechesa (Seoul: Inmul-kwa Sasangsa, 2007), 428; Kim, Ilbon-ǔl Kümhata, 82-4.

73 Chungang Ilbo and Tongyang Pangsong, Chungang Ilbo-Tongyang Pangsong Sipnyŏnsa (Seoul: Chungang Ilbo· Tongyang Pangsong), 265-66. 
plorable tone. ${ }^{74}$ This pre-existing influence of the Japanese media on Pusan, however, became much stronger with the opening of the Tokyo Olympics. In Pusan, many tearooms with TV sets were turned into theaters where people who wanted to watch the Olympic broadcast on Japanese public TV gathered. ${ }^{75}$ Even President Park went to Pusan in order to watch an Olympic boxing match with the expectation of seeing South Korea win its first gold medal in the Olympics, but he was disappointed at the defeat of the South Korean boxer by a Japanese adversary. ${ }^{76}$ The Olympic TV boom increased the number of TV sets in Pusan from approximately 600 in 1962 to 4,000 in $1964 .{ }^{77}$ From the perspective of the relationship between spillover and mega sports events, it is reminiscent of the case of East Germany before the World Cup in 1954 when 'more TV sets were sold than ever before,' particularly 'in the regions where the public service broadcasting of West Germany could be received. ${ }^{78}$

In Japan, the Olympic TV boom was enormous. 'More than ninetyeight per cent of the respondents' to a large-scale survey of the television audience 'watched Olympic events on television, and sixty-one per cent of them watched frequently.' ${ }^{79}$ It was analyzed that most of them watched Olympic events on black and white rather than color TV. The most popular Olympic event (based on TV ratings in Japan) was the female volleyball final between Japan and the Soviet Union with a rating of eighty five per cent, which was the highest viewing rate in Japanese TV

74 Kwŏn Yŏngtae, “Chungsin Charyŏyaketnunte,” Donga Ilbo, January 25, 1964.

75 "Ilson Mŏmchuko Tongkyŏng-ŭro," Chosŏn Ilbo, October 11, 1964.

76 “Chŏngka Naksu," Kyŏnghyang sinmun, October 24, 1964.

77 “Pusan-e TV Boom,” Donga Ilbo(extra edition), October 11, 1964; Kim, Ilbon-ǔl Kümhata, 86-7.

78 Lothar Mikos, "German football - a media-economic survey: The impact of the KirchMedia Company on football and television in Germany," in German Football: history, culture, society, eds. Alan. Tomlinson and Christopher. Young (New York: Routledge, 2006), 144.

79 Slater, “Tokyo 1964,” 170 
history. ${ }^{80}$

Fundamentally, Japan was an archrival for South Korea to be dominated but, at least in the 1960s, Japan was more a country to be emulated by South Korea. In fact, Japan exerted a strong influence on the domain of South Korean sports. One of the most obvious cases was with the coach who led the Japanese female volleyball team to Olympic gold. After the Tokyo Olympics, South Korean female volleyball aspired to follow in the footsteps of their Japanese counterparts, particularly in terms of the Japanese coach's training method. The coach, Daimatsu Hirofumi, was invited to train the South Korean female volleyball team in the build up to the 1976 Olympics. A former team player recounted that the Japanese coach's intensive and defense-oriented training of thirteen hours a day over five weeks led the team to bronze in $1976 .^{81}$

Aside from the volleyball coach, Kim Üit'ae, the bronze medalist in judo at the Tokyo Olympics would have a tremendous impact on the development of South Korean judo. Kim had honed his judo skills from one of the most prestigious university judo teams in Japan and was appointed as the national team coach of South Korean judo before the Montreal Olympics in 1976 where his team unexpectedly won one silver and one bronze medal. ${ }^{82}$ Another South Korean medalist at the Tokyo Olympics, the wrestler Chang Changsŏn, reported that the month long training in Japan with Japanese wrestlers greatly helped him to obtain a silver medal in 1964. He made the request to President Park for the training in Japan in an attempt to hone his wrestling skills after taking a silver medal in the 1962Asian Games. ${ }^{83}$ He would later become a champion in the World Amateur Wrestling Championship in 1966, which was the first victory of any South Korean athlete in a world sports championship after the libera-

80 Furukawa Takahisa, Showa Zengosi Chu (Tokyo: Kodansha, 2006), 156-58.

81 "Montreal Oryun paeku Tongmetal," Kyŏnghyang sinmun, November 13, 1991.

82 Ohsima, Tamasiino Soukoku, 146-47.

83 "Chukchi-sŏ Chunpihan Tokyo Olympics," Kyŏnghyang sinmun, November 4, 1997. 
tion of Korea in $1945 .{ }^{84}$

The overall result of one silver medal and two bronze medals for South Korean athletes at the Tokyo Olympics had been the best record of South Korea in its Olympic history since its first Olympic participation in $1948 .{ }^{85}$ However, this positiveperformance fell short of public expectations. On the contrary, South Koreans' unprecedented interest in sports during the Olympics pressured the government to put sports development and promotion at the top of the South Korean agenda under the twin banners of anti-Japanese sentiments and anti-communism.

\section{Conclusion}

As a luminary in Japanese studies, Edwin Reischauer has pointed out in his book that the Tokyo Olympics in 1964 gave 'the Japanese a chance to show the world their achievements, which they did with great pride and gusto, in what were generally recognized to be the finest Olympic Games to date. ${ }^{86}$ For Japan, the Olympics were a showcase for the world to witness its economic miracle that would eventually make Japan by the end of the 1960s the third largest economy in the world. ${ }^{87}$ Its national morale stemming from the successful hosting of Olympics and athletic achievements was also high enough for the Japanese to not feel a sense of isolation and inferiority anymore, which was an enduring sentiment since their defeat in the Second World War. ${ }^{88}$

84 “Chang Changsŏn Kŭmmetal Hoekt ŭk Piwha," Kyŏnghyang sinmun, June 21, 1966.

85 “64 yŏnto-ŭi Sports Chongkyŏlsan,” Donga Ilbo, December 19, 1964.

86 Edwin O. Reishauer, Japan: The Story of a Nation, Fourth edition (Tokyo: Tuttle Publishing, 1990), 249.

87 Edwin O. Reishauer, The Japanese (Tokyo, the Charles Tuttle Company, 1977), 115.

88 Edward Seidensticker, A History of Tokyo 1867-1989: From EDO to SHOWA: The Emergence of the World's Greatest City (Tokyo: Tuttle Publishing, 2019), 495. . 
However, the skyrocketing economy in Japan was to a greater extent a result of the Korean War between 1950 and 1953. As the War broke out, America attempted to make Japan a military logistics base and a resort for its troops, which entailed a special procurement boom particularly in cement, pulp, fertilizers and pachinko. ${ }^{89}$ The American government also came to perceive the Japanese islands as an important bulwark to prevent the spread of communism, a shifting international situation that paved the way for the normalization of Japan with the 1952ctreaty of San Francisco. ${ }^{90}$

In light of this, it was an irony that the two protagonists of the Korean War would be scheduled to compete against each other for the first time in their Olympic history at the Olympiad hosted by the biggest beneficiary of the War. However, the battle between the two Koreas was mostly invisible with the purpose of ideologically influencing the split Korean community in Japan because of North Korea's indignant withdrawal over the IAAF's ban on GANEFO participants, including its world record holder, Sin Kŭmtan. After the Tokyo Olympics, North Korean sports gained momentum. The amalgamation between sports and the idea of Chuche began to have an effect in the world arena from the mid-1960s. The culmination of this fusion was North Korea's World Cup success in 1966. The medal competition between the ideological rivals in the Olympics began in 1972 when North Korea obtained its first gold medal in rifle shooting. Their southern counterparts had to wait four years for their first Olympic gold medal but this long-anticipated sporting rivalry spurred on the rapid growth of South Korean sports in the next decade.

The Tokyo Olympics made the South Korean government recognize clearly that its sports should gear up for the two rivalries against North Korea and Japan. ${ }^{91}$ For South Korea, strongly entrenched in anti-

89 Katsutoshi Hando, Showa-si, Sengohen 1945-1989 (Tokyo: Heibonsha, 2018), 297-304, 304; Reischauer, Japan: The Story of a nation, 200.

90 Reischauer, Japan: The Story of a nation, 200-2.

91 Sayuri Guthrie-Shimizu, "Diffusion and Transformation of Western Sports in 
communism at the time, all sporting contests against North Korea were regarded as must-win and make-or-break games. In the Sports field, the South Korean hostility towards North Korea was very much similar to their antipathy towards Japan. Yet, at the outset, Japanese sports were assessed as a good example upon which South Korea sought to model itself. At the same time, however, South Korea needed the emergence of an anti-Japanese champion in sport, since anti-Japanese sentiments were pervasive in South Korean society and had escalated amid treaty negotiations between South Korea and Japan. It would be no exaggeration to say that external pressures from North Korea and Japan came to be the twin driving forces facilitating development of South Korean sports. It was the Tokyo Olympics that shaped South Korean nationalism through the success of Japanese athletes and the foreseeable sporting competitions against North Korea.

\section{References}

Newspapers and Magazines

1. Chosŏn Ilbo

2. Chungang Ilbo

3. Donga Ilbo

4. Hankyŏre sinmun

5. Kyŏnghyang sinmun

6. Nodong sinmun

7. The Pyongyang Times

8. Wŏlgan Chosŏn

9. Xinwen Zhanxian

North Asia," eds. The Oxford Handbook of Sports History (Oxford: Oxford University Press, 2017), 283. 
Books and Journals

10. Abel, Jessamyn R. "When Athletes Are Diplomats: Competing for World Opinion at the Tokyo Olympiads." In The East Asian Olympiads 1934-2008: Building Bodies and Nations in Japan, Korea, and China, edited by William Tsutsui and Michael Baskett, 35-49. Leiden: Global Oriental, 2011.

11. Andrews, David L. and Stephen Wagg, "Introduction: War minus shooting?." In East Plays West: Sport and the Cold War. edited by Stephen.Wagg and David L. Andrews, 1-9. NY: Routledge, 2007.

12. Cho, Heeyeon. Park Chung Hee-wa Kaebaldokjaesidae. Seoul: Yŏksapipyŏngsa, 2007.

13. Chŏng, Jaechŏng. Chuje-wa Chaengchŏm-ŭro Iknŭn 20 saeki Hanilkwankyesa. Seoul: Yŏksapipyŏngsa, 2019.

14. Chungang Ilbo and Tongyang Pangsong, Chungang Ilbo-Tongyang Pangsong Sipnyŏnsa. Seoul: Chungang Ilbo-Tongyang Pangsong.

15. Cummings, Bruce. Korea's Place in the Sun: a Modern History. New York, W. W. Norton \& Company, 2005.

16. Furukawa, Takahisa. Showa Zengosi Chu. Tokyo: Kodansha, 2006.

17. Guthrie-Shimizu, Sayuri."Diffusion and Transformation of Western Sports in North Asia." In The Oxford Handbook of Sports History, edited by Robert Edelman and Wayne Wilson, 273-86. Oxford: Oxford University Press, 2017.

18. Guttmann, Allen. The Olympics: A History of the Modern Games, Second Edition. Urbana and Chicago: University of Illinois Press, 2002.

19. Guttmann, Allen and Thompson, Lee. Japanese Sports: A History Honolulu, University of Hawaii Press, 2001.

20. Han, Sŏkchŏng, Manchu Modern: 60 Nyŏndae Hankuk Kaebal Cheje-ŭi Kiwŏn. Seoul: Munhak-gwa Chisŏngsa, 2016.

21. Hando, Katsutoshi. Showa-si, Sengohen 1945-1989. Tokyo: Heibonsha, 2018

22. Hŏ, Chinsŏk. Sports Konghwakuk-ŭi Tansaeng Seoul: Tongkuk 
Taehakkyo Chulpanpu, 2010.

23. Kang, Chunman. Hankuk Taechung Maechesa. Seoul: Inmul-kwa Sasangsa, 2007.

24. Kim, Kwanghi. "A, Kŭm Tan a Aekŭlnŭn Maŭm.” In Sports-wa Hamkyehan Yŭlkwang-ŭi Sewŏl, edited by. Hankuk Cheyuk Unroninhoe, 59-62. Seoul: Chei \& Chei Media, 2015.

25. Kim Pyŏngha et al., Urinara Chukku. Pyŏngyang: Cheyuk Chulpansa, 1963.

26. Kim, Sŏngkŭn. Kolchi-rŭl Ildŭng-ŭro. Seoul: Chaŭm-kwa Moŭm, 2009.

27. Kim, Sŏngmin Ilbon-ŭl Kümhata: Kŭmche-wa Yokmang-ŭi Hankuk Taechungmunwhasa 1945-2004. Pachu: Kŭlhangari, 2017.

28. Ko, Tuhyŏn. Ǔri-to Haenaelsu Itta: Hankuk Olympic Tochŏn Panseki. Seoul: Hankuk Pangsong Saŏptan, 1982.

29. Lee Hangnae and Kim, Dongsun. Pukhan-ŭi Ch'eyuk. Yongin: Hankuk Haksuljŏngposa, 2001.

30. Lee, Jongsung. A History of Football in North and South Korea C. 1910-2002: Development and Diffusion. Oxford: Peter Lang, 2016.

31. Lothar Mikos, "German football - a media-economic survey: The impact of the KirchMedia Company on football and television in Germany." In German Football: history, culture, society, edited by Alan Tomlinson and Christopher Young, 143-54. New York: Routledge, 2006.

32. Merkel, Udo. "Sport, Politics and Reunification - Comparative Analysis of Korea and Germany." The International Journal of the History of Sport 26, no. 3 (February 2009), 406-28.

33. Morris-Suzuki, Tessa. Exodus to North Korea: Shadows from Japan's Cold War. Lanham: Rowman \& Littlefield Publishers, 2007.

34. Ohsima, Hiroshi. Tamasiino Soukoku Zainichi Supotsu Eiyu Retsuden. Tokyo: Kodansha, 2012.

35. Reishauer, Edwin O. Japan: The Story of a Nation, Fourth edition. Tokyo: Tuttle Publishing, 1990.

36. Reishauer, Edwin O. The Japanese. Tokyo, the Charles Tuttle Com- 
pany, 1977.

37. Seidensticker, Edward. A History of Tokyo 1867-1989: From EDO to SHOWA: The Emergence of the World's Greatest City. Tokyo: Tuttle Publishing, 2019. .

38. Slater, John. "Tokyo 1964." In Encyclopedia of the Modern Olympic Movement, edited by John Findling and Kimberly Pelle, 165-72. Westport, CT: Greenwood Press, 2004.

39. Xu, Guoqi. Olympic Dreams: China and Sports 1895-2008. Cambridge: Harvard University Press, 2008.

40. Yoshizawa, Fumitoshi. Hyŏntae Hanil Munche-ŭi Kiwŏn. trans, Hyŏnchu Ri. Seoul: Ilchokak, 2019.

41. Yu, Yongtae, Park, Chinwoo and Park, Taekyun. Hamke Iknun Donga sia Kunhyŏntaesa 2. Pachu: Changpi, 2011.

42. Yun, Kŏncha, Zainich-ŭi Chŏngsinsa, trans, Pak Chinwoo. Seoul: Hankyŏrae Chulpansa, 2015. 
〈Abstract〉

\section{'When Sport Met Ideology and Colonial Bitter Memories': The Impact of the 1964 Tokyo Olympics on North and South Korean Sports}

Jongsung Lee

The Tokyo Olympics held in 1964 opened the floodgates for a sporting rivalry between North and South Korea at the height of the Cold War. Although this keen competition would not take place on the field, the two Koreas carried out an 'ideological battle' to woo the Korean community in Japan, who were split by the pro-North Korean organization and the pro-South Korean organization. Deeply discontented by the ban imposed on a North Korean star athlete, the North Korean contingent withdrew from the Olympics at the last minute. Meanwhile, South Korea had the best record in its Olympic history at Tokyo, but this sporting accomplishment was completely dwarfed by the startling success of its former colonizer. In the wake of the Olympics, the public antagonism towards Japan reached its climax, mainly due to the treaty between Japan and South Korea in which the South Korean government sought to receive economic assistance rather than an official apology from Japan. Under these circumstances, the two Koreas would gear up for imminent sporting wars against each other and against Japan and the Western capitalist countries by restructuring their elite sports system under the banners of Chuche ideology in North and anti-communism coupled with antiJapanese sentiments in South. Key words: Olympics, The Cold War, North Korea, South Korea, Anti-communism, Anti-Japanese sentiments

Keywords: the Olympics, North Korea, South Korea, Anti-Japanese sentiment, Cold war 
〈국문초록〉

\section{냉전과 탈 식민주의: 1964년 도쿄 올림픽이 한국과 북한 스포츠에 미친 영향}

이종성 (한양대)

1964년에 열린 도쿄 올림픽은 냉전 분위기가 고조되던 시기에 한국과 북한 간 스포 츠 라이벌 의식을 촉발시킨 대회였다. 비록 두 국가간의 스포츠 대결이 도쿄 올림픽에 서 펼쳐지지는 않았지만 한국과 북한은 조총련과 민단으로 나뉘어져 있던 재일사회의 지지를 얻어내기 위해 ‘이념전쟁'을 수행했다. 자국의 한 육상선수에 대한 출전금지 조 치에 크게 불만을 갖고 있던 북한 선수단은 대회 개막 직전 올림픽 참가를 포기했다. 반면 한국은 도쿄 올림픽에서 올림픽 역사상 가장 좋은 성적을 기록했지만 이 성과는 일본의 눈부신 성공에 의해 가려졌다. 일본으로부터 진정한 사과를 받기보다 경제적 원조를 받기 위해 추진됐다는 평가를 받고 있던 한일협정의 여파로 도쿄 올림픽 이후 한국인들의 일본에 대한 적대감은 절정으로 치닫고 있었다. 이와 같은 분위기 속에서 한국과 북한은 두 국가간의 임박한 ‘스포츠 전쟁’은 물론이고 일본과 서방 국가들과의 스포츠 무대에서의 경쟁을 위해 북한에서는 주체사상, 그리고 한국에서는 반공주의 반 일감정이라는 기치하에 엘리트 스포츠 시스템을 전면적으로 개혁했다.

주제어: 올림픽, 냉전, 북한, 한국, 반공주의, 반일감정 
